\title{
Determination of Internet Banking Usage and Purpose with Explanation of Data Flow Diagram and Use Case Diagram
}

\author{
R. Ganesh, G. Prabu
}

\begin{abstract}
The performance of the banking industry rapidly urbanized with the support of technological development. The advancement of digitalization of banking industry should help the customers to make their transactions without being in person in banks. This study is going to explicate the usage pattern and purpose of internet banking users, for this intention the data flow and use case diagram methods are adopted to explain the process of varies activity that is highly related to banking industry. The 121 samples were collected using questionnaire method in an around Salem District. Friedman rank correlation and One-Way ANOVA were employed for the study. In the usage pattern there are three factors like perceived usefulness, perceived ease of use and perceived risk have been used for the study. The fund transfer is the most influenced factor in the purpose of internet banking users.
\end{abstract}

Keywords: Internet Banking, Data Flow Diagram, Use Case Diagram

\section{INTRODUCTION}

According to [1] internet banking gives acquire process, delivers information to the customers and furthermore it provides convenient, reliability, and expedient services [2], [3]. The internet banking reduces the time and it is an easy access throughout the world, also their study provides the determination of internet banking adoption and behavioural intention to internet banking used the Technology Acceptance Model (TAM) [4]. He gives an opinion electronic banking is changing the banking industry and it gives major effects on banking relationships. It is applicable for mutually networks, internet, banking products and services. These services increase customer loyalty, customer access, attract new customers and reduce customer attrition. He uses the several factors to determine the internet banking adoptions likely psychological factor, complexity, risk, convenience, security, cost, and compatibility. Studied by [5]. Internet banking and e-commerce, e-business and financial services rapidly increases in developing economy. However [6], taken the variable used for their study two groups namely four internet bank adopter and four non internet banking adopters for these purpose they used factors

Revised Manuscript Received on March 05, 2020.

Dr. R. Ganesh*, Assistant Professor, Department of Commerce, Guru Nanak College,Velachery, Chennai- 42.Tamil Nadu, India, Email:ganeshvr1983@gmail.com

Dr.G.Prabu, Assistant Professor, Department of Commerce, Guru Nanak College,Velachery, Chennai- 42. Tamil Nadu, India, Email: pprabug@gmail.com.

(C) The Authors. Published by Blue Eyes Intelligence Engineering and Sciences Publication (BEIESP). This is an open access article under the CC BY-NC-ND license (http://creativecommons.org/licenses/by-nc-nd/4.0/)
* Correspondence Author

convenience, easy to use, awareness, security and trust. [7] used conceptualized research model determining the internet banking users in the course of financial security, trust, information quality time and money. Used the PLS model for identified factor influenced internet banking adoption with help of following eight factors specifically aware and ease of use, aware and usefulness, ease of use and adoption, aware and reliability, usefulness and ease of use, usefulness and reliability, reliability and adoption and usefulness and adoption studied by [8] In addition [9] analysed to test the variable similar to compatibility, observability, relative advantage, complexity, perceived risk, trial ability and service satisfaction. [10] moreover supported factor influenced and adopted the univesity student in the course of their investigaction attitude, usefulness, trust perceived ease of use, perceived behavioural control and social control. [11] emphasized the mobile commerce, and used the several theoretical model background reminiscent of Theory of Reason Action (TRA), Theory of Planned Behavior (TPB) and Diffusion Innovation Theory (DOI), moreover they used for factor analyses to identify the factors that is directly affected by M-Commerce. [12] They identified that internet usage is the more readily available in present business environment because of technological spread, internet banking service customers increased benefits by using the internet they employed Technology Acceptance Model (TAM).

\section{A.Factors Determination}

To conduct this study three factors like perceived usefulness, perceived ease of use and perceived risk are taken each factor contains five variables. The following some previous studies that proven by various researchers that could help the present study. Two decade before [13] investicated the two valid measurement scale of perceived usefulness and perceive ease of use these variable are hypothesized fundamental user acceptance model, this study discussed with detailed theoretical and analytical models. For this reason perceived usefulness perceived ease and perceived risk of use variables were developed scale items and then tested its reliability and validity. Similar study made by [14] [15], [16] used Technology Acceptance Model (TAM), perceived ease of use, perceived usefulness and bheavioural intention attiudes. However analysed [17] perceived ease of use perceived usefulness and ambient intelligence function are in the field of office environment.

Published By:
Blue Eyes Intelligence Engineering \& Sciences Publication (C) Copyright: All rights reserved. 


\section{B. Data Flow Diagram}

Data Flow Diagram (DFD) is a graphical representation of the "flow" of data through an information system. DFDs can also be used for the visualization of data processing (structured design).On a DFD, data items flow from an external data source or an internal data store to an internal data store or an external data sink, via an internal process. A DFD provides no information about the timing of processes, or about whether processes will operate in sequence or in parallel. The below flow diagram 1 shows evidence of preprocessing of internet banking graphical representations. The four components fund transfer; account statement, ticket booking and online shopping which is useful visualize the data processing. The flow diagram 2 illustrates that the fund transfer process which is completed only after checking the account details and receiver details. The receiver who is receives the fund opposite to the depositor. The flow diagram 3 represents that the ticket booking process during the payment there are variety of process made by the payer to booking a ticket such as payment, enquiry, and seat availability, account number and bank details checking and finally get a proof of receipt. All those process explained by graphical representations models with help Data Flow Diagram (DFD).

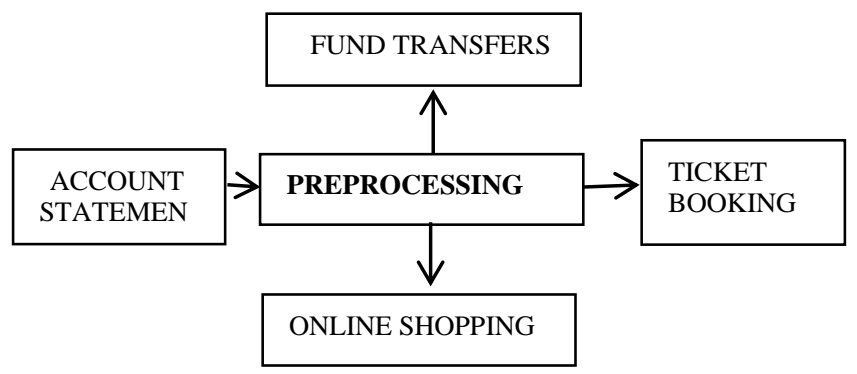

Diagram 1 Preprocessing of Internet Banking

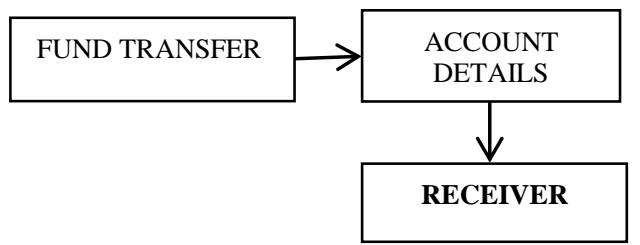

Diagram 2 Processing Fund Transfer

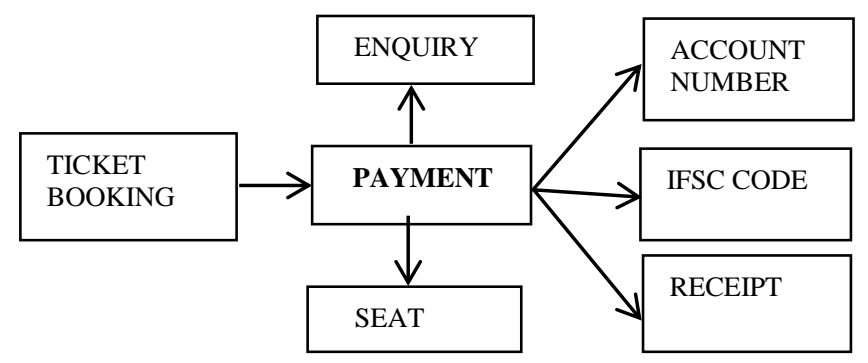

Diagram 3 Processing Ticket Booking

\section{Use-Case Diagram}

Use case diagrams present a high level view of how the system is used as viewed from an outsider's (actors) perspective during the design phase, use case diagrams used to specify the behavior of the system as implemented. These internal and external agents are known as actors. So use case diagrams are consists of actors, use cases and their relationships. The diagram is used to model the system/subsystem of an application. A single use case diagram captures a particular functionality of a system. A use case as shown in corresponds to a sequence of transaction, in which each transaction is invoked from outside the system (actor) and engages internal objects to interact with one another and with the system's surroundings. The five modules were elucidates through Unified Modeling Language (UML), a use case diagram. There are five purposes such as fund transfer, ticket booking, online shopping, generate account statement and bill payment which often used by the internet banking users. Further the use-case diagrams explain the internal and external users of internet banking.

\section{Fund Transfer}

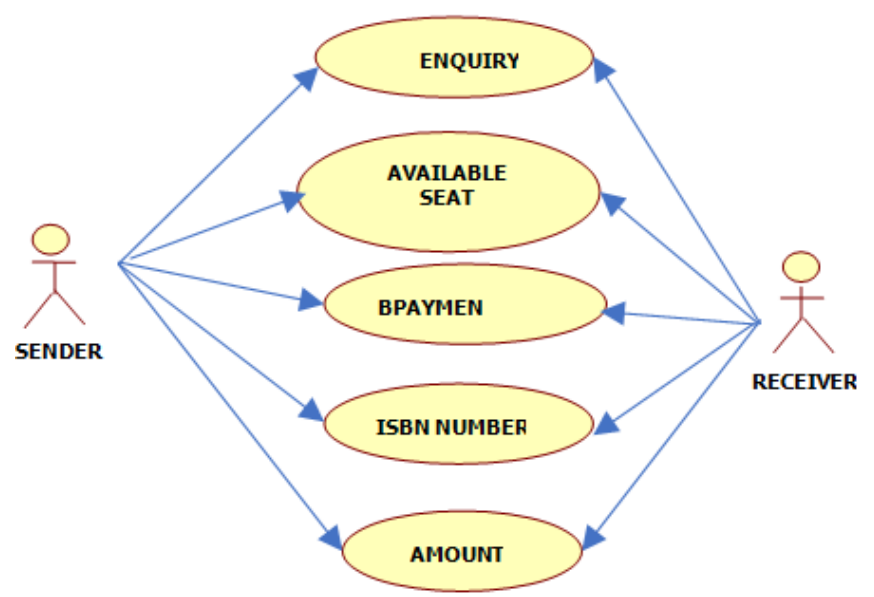

Processing of fund transfer Diagram - 4

\section{Ticket Booking}

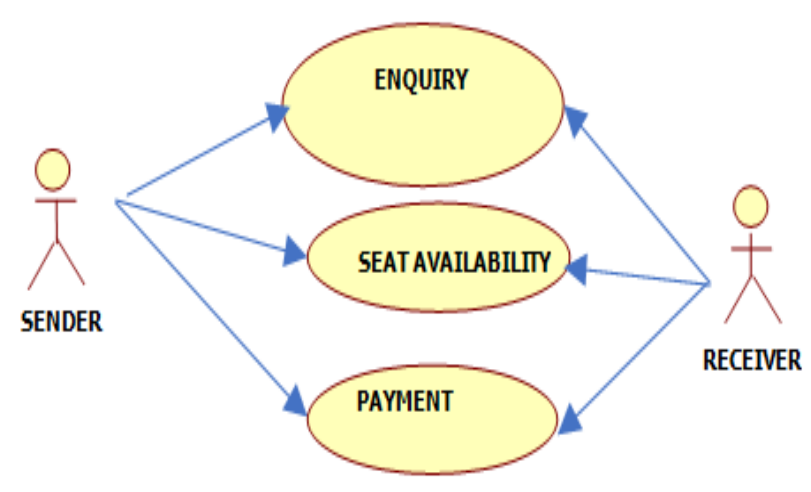

Processing of Ticket Booking Diagram - 5

\section{Online Shopping}

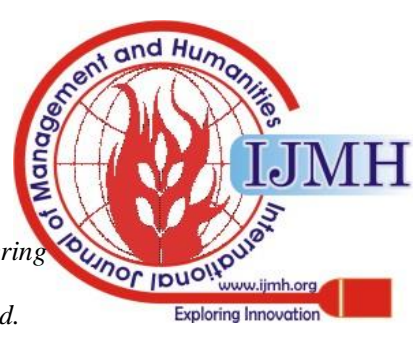




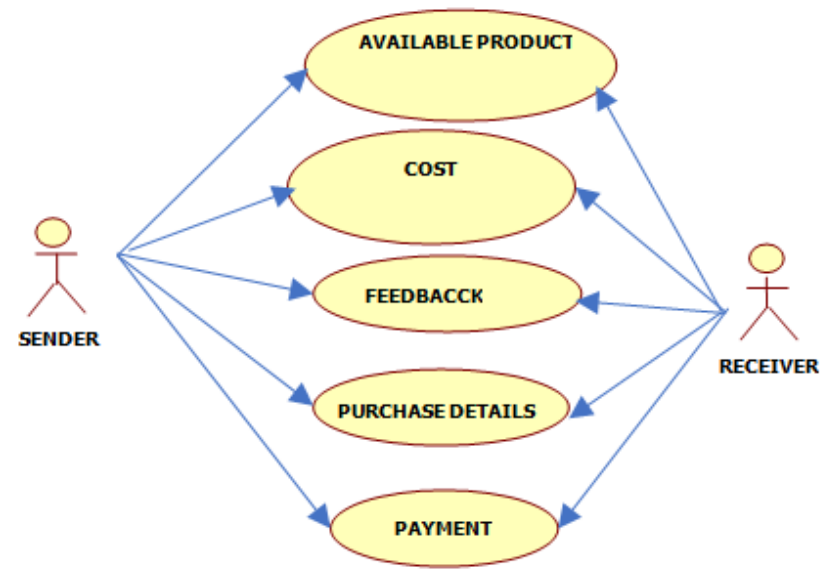

Processing of Online Shopping Diagram - 6

\section{Generate Account Statement}

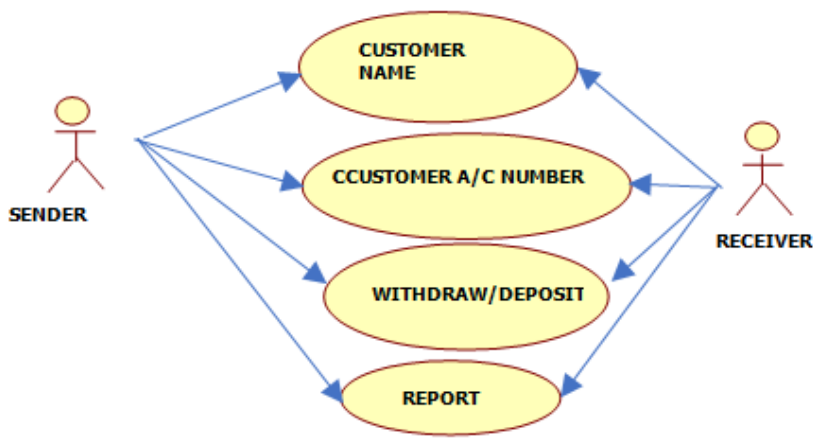

Processing of Generate Accounting Statement Diagram - 7

\section{Bill Payment}

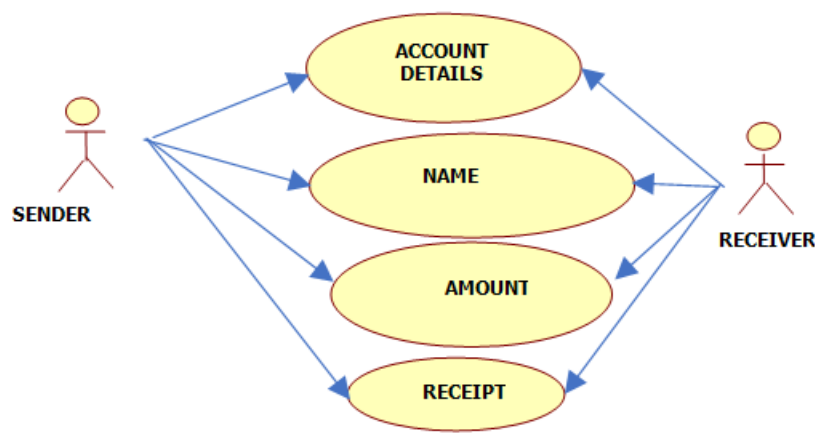

Processing of Bill Payment Diagram - 8

\section{REVIEW OF LITERATURE}

[18] this paper evaluate the demand for internet banking in a small economy of Mauritius, the purpose of this paper is to find out the most influenced factor that is affecting internet banking users for this purpose they use the following factor that is perceived ease of use, perceived security, reluctance to change and privacy. They taken 400 individual samples analyse the data and find the result was the banker must be encourage their customer to using internet banking. [19] His studied the internet banking adoptions in Tunisia determine the factors influenced through the internet bank user and non internet bank users. He used for factor analysis and regression technique identify the internet banking services following factors like channel convenience, security perception, information of online banking, prior internet knowledge and perceived risk in Tunisia. [20] have analyzed Technology Acceptance Model (TAM) internet banking adoption from the cross sectional data collected survey their vast study gives number of 1286 respondents were selected for this study in Yemen. And also they employed Structural Equation Model (SME) analyses the data used the relative factors perceived ease of use, trust, attitude towards internet banking adoption and intention of internet banking users. [21] this paper investigated adoption of electronic banking through the exploratory research in Nigeria. They collected from the sample within the university academic and non academic stuff and also taken variable for six that is security cost, ease of use, awareness cost, reluctance to change and accessibility [22] studied the factors influence internet banking adoption Kenya this study determine the internet banking consumers how affect the internet banking adoption as well as find out the website security how affects of internet banking consumers. He found the result those men customer involved more than female customers. Multistage regression analysis also used to analyses the data [23] this study examine identify the factors that determine customers adoption of internet banking in India, they considered seven factors for determining the factors namely performance expectancy, attitude, trust social influence awareness and self-efficacy and besides Unified Theory of Acceptance and Use of Technology (UTAUT) model was used. Finally they recommended that the internet bankers keep making awareness programme to the customers [24] explore internet banking adoption towards developing economies for this reason he used more than a few theoretical model Technology Acceptance Model (TAM), Theory of Reasoned Action (TRA), Diffusion of Innovation Model (DIM) and Theory of Planned Behaviour Model (TPB). Lastly the findings suggest that customer employment status is significantly associated with the internet banking adoption and usage, bankers need to concentrated increase more full time employees [25] conducted the study by online banking adoption of Nigerian customers they use extended Technology Acceptance Model (TAM) was modified with awareness, trust, technology and quality. For this intention they use principle and component factor analysis was used.

\section{Need for the Study}

Banking industry plays a vital role for every wealthy economic country like India it is not possible without the customers support. In olden days customers directly go to the bank for making their financial transactions such as money deposit and money withdrawal, but the recent days it will be changing because of rapid development in the banking industry the modern technology help us to do that things. Recent innovation in the banking industry should attract the customer for becoming an account holder of a particular bank. The customer mostly using banking systems for making fund transfer, purchasing, bill payment and recharge purpose.

The main intention of the study should clarify the purpose and usage pattern of internet banking users with help of Data flow diagram and Use case diagram.

Blue Eyes Intelligence Engineering adoption. And he framed the research model used the

\section{Published By:} \& Sciences Publication (C) Copyright: All rights reserved.

and $\mathrm{Hu}$

( 


\section{Scope of the Study}

Internet banking should attract the customer with support of modern technology. Most of the customer using internet banking for fund transfer, online shopping, bill payment, ticket booking, recharge facilities, western union money transfer and generate of their account statement it could be done within a few mints, while doing these thing customers faced benefits as well as problems. The ultimate goal of the study is to analyse the purpose and usage patterns like perceived usefulness, perceived ease of use and perceived risk.

\section{Objective of the Study}

To prove the above problem the following objective were farmed.

1. To analyse the purpose and the usage pattern of internet banking user adaption with adopting of data flow and use case methods.

\section{Hypothesis of the Study}

For tested the above objectives the following hypotheses has been framed and it should be tested with various statistical tools.

1. There is no significant difference between the purpose and the usage pattern of internet banking user adaption with regard to their socio economic profiles.

\section{METHODS}

Descriptive research design describes the characteristics of the group of target population such as age, gender, attitude and behaviour. Therefore this study has been based on descriptive research design. Studied by [26] this research report is based on convenience sampling under nonprobability sample design by [27] the collection of data is considered to be one of the most important aspects in the research methodology. Both primary and secondary data are used in this study in order to meet the requirements of the purpose. Under this study primary data are collected by using self-administered questionnaire. Secondary data are collected from the websites, magazines, books, periodical surveys and library books. The area of this study is Salem District. The collected data are analyzed by preparing suitable tables. The information collected with the help of self - administered questionnaire are tabulated and analyzed by using various statistical measures like Percentage Analysis, Friedman Rank Correlation and One-Way (ANOVA), Owing to paucity of time and fund, the size of the sample is restricted to 121 . The study is confined to the internet banking users the result of the study only reflect internet banking users only.

\section{Testing the Reliability}

Cronbach's Alpha is the most common measuring method of internal consistency or reliability. It is most commonly used when one has multiple Likert questions in a survey and interview schedule to determine the reliability of variables. In the purpose of using internet banking five variables are taken like fund transfer, ticket booking, online transfer, generate account statement and bill payment the statistical reliability 0.716 which is more than 70 therefore all the variables of suitable for the further analysis. In the usage pattern there are three factors carried for this study and test reliability statistics. The first factor Perceived Usefulness which is includes five variables like internet banking usage improve my quality, internet banking gives me a control of my work, internet banking improve my performance, internet banking making easier to do my work and internet banking useful for me. The overall reliability for this factor is 0.711 which is more than $70 \%$ and it's suitable for further analysis. Second factor Perceived ease of use which is consists five variables such as internet banking confusion for me, internet banking very easy for use, internet banking needs some mental effort, internet banking in understandable and internet banking ease of learning. Aggregated reliability score is 0.656 which is more than $65 \%$ therefore the variables taken for the studies are fit for the upcoming analysis. The last factor which is comprises five variables namely I am confident over the security aspect of internet banking, my internet banking transactions will be known to others, internet banking transaction can be theft by others, I have confidence in the security of the exiting internet banking transaction networking and internet banking transaction and payment can protect my information and privacy. The cumulative reliability score is 0.686 which is more than $68 \%$ consequently all the variables are appropriate for the study.

\section{ANALYSIS AND INTERPRETATION OF DATA}

Socio Economic Profile of the Internet Banking Users

Table - 1

\begin{tabular}{|c|c|c|c|c|}
\hline $\begin{array}{c}\text { Demographic } \\
\text { Factors }\end{array}$ & Groups & Frequency & Percent & $\begin{array}{c}\text { Valid } \\
\text { Percent }\end{array}$ \\
\hline \multirow{3}{*}{ 1. Gender } & Male & 110 & 90.9 & 90.9 \\
\hline & Female & 11 & 9.1 & 9.1 \\
\hline & Total & 121 & 100.0 & 100.0 \\
\hline \multirow{3}{*}{ 2. Marital Status } & Married & 41 & 33.9 & 33.9 \\
\hline & Unmarried & 80 & 66.1 & 66.1 \\
\hline & Total & 121 & 100.0 & 100.0 \\
\hline \multirow{5}{*}{$\begin{array}{l}\text { 3. Educational } \\
\text { qualification }\end{array}$} & Up to HSC & 14 & 11.6 & 11.6 \\
\hline & $\begin{array}{l}\text { Under } \\
\text { Graduate } \\
\end{array}$ & 43 & 35.5 & 35.5 \\
\hline & $\begin{array}{l}\text { Post } \\
\text { Graduate }\end{array}$ & 31 & 25.6 & 25.6 \\
\hline & Diploma/ITI & 33 & 27.3 & 27.3 \\
\hline & Total & 121 & 100.0 & 100.0 \\
\hline \multirow{5}{*}{$\begin{array}{c}\text { 4. Occupational } \\
\text { Status }\end{array}$} & $\begin{array}{l}\text { Govt., } \\
\text { Employee }\end{array}$ & 6 & 5.0 & 5.0 \\
\hline & $\begin{array}{l}\text { Private } \\
\text { Employee }\end{array}$ & 85 & 70.2 & 70.2 \\
\hline & Businessman & 14 & 11.6 & 11.6 \\
\hline & Others & 16 & 13.2 & 13.2 \\
\hline & Total & 121 & 100.0 & 100.0 \\
\hline \multirow{4}{*}{ 5. Age group } & Young age & 31 & 25.6 & 25.6 \\
\hline & Middle age & 60 & 49.6 & 49.6 \\
\hline & Old age & 30 & 24.8 & 24.8 \\
\hline & Total & 121 & 100.0 & 100.0 \\
\hline \multirow{4}{*}{$\begin{array}{l}\text { 6. Monthly } \\
\text { income }\end{array}$} & Low Income & 33 & 27.3 & 27.3 \\
\hline & $\begin{array}{l}\text { Average } \\
\text { Income }\end{array}$ & 55 & 45.5 & 45.5 \\
\hline & High Income & 33 & 27.3 & 27.3 \\
\hline & Total & 121 & 100.0 & 100.0 \\
\hline \multirow{3}{*}{ 7. Types of $\mathrm{A} / \mathrm{c}$} & Current A/c & 16 & 13.2 & 13.2 \\
\hline & Saving A/c & 105 & 86.8 & 86.8 \\
\hline & Total & 121 & 100.0 & 100.0 \\
\hline \multirow{3}{*}{ 8. Type of Bank } & $\begin{array}{l}\text { Public sector } \\
\text { bank }\end{array}$ & 62 & 51.2 & 51.2 \\
\hline & $\begin{array}{l}\text { Private } \\
\text { sector bank }\end{array}$ & 59 & 48.8 & 48.8 \\
\hline & Total & 121 & 100.0 & 100.0 \\
\hline
\end{tabular}

Sources: Questionnaire Method

Inference

Published By:

Blue Eyes Intelligence Engineering \& Sciences Publication 
The above demographic factor 1 clearly stated that 90.1 per cent of the male users are using internet banking. 9.1 per cent of the female users are using internet banking. According to the gender most of the male users are using internet banking. We understood from the above demographic factor 2, 66.1 per cent of the married users are using internet banking. 33.9 per cent of the unmarried users are using internet banking. When compared with married users' unmarried users are high. We observed from the above demographic factor 3, 35.5 per cent of the internet banking users are completed their under graduation, 27.3 per cent of the internet banking users are completed their diploma/ITI, 25.6 per cent of the internet banking users are completed their post graduation and finally 11.6 per cent of the internet banking users qualification is up to HSC. It clearly stated that the above demographic factor 4, 35.5 per cent of the internet banking users are completed their under graduation. The above table illustrate that 70.2 per cent of the internet banking users are private employees, 13.2 per cent of the internet banking users are others, 11.6 per cent of the internet banking users are businessman and 5.0 per cent of the internet banking users are government employees. It eventually shows that 70.2 per cent of the internet banking users is private employees. We understood from the above demographic factor 5, 49.6 per cent of the internet banking users are comes under the age group of middle age, 25.6 per cent of the internet banking users are comes under the age group of young age and 24.8 per cent of the internet banking users are comes under the age group of old age. It clearly stated that the most of the internet banking users are comes under the age group of middle age group. We have a clear understanding from the above demographic factor $6,45.5$ per cent of the internet banking users earning average income and remaining internet banking user fall in the low income and high income. It obviously shows that most of the internet banking users getting average income. Derived from the above demographic factor 7, 86.6 per cent of the internet banking users is having saving account and 13.2 per cent of the internet banking users are having current account. It eventually shows most of the internet banking users are maintaining saving account. From demographic factor 8, we observed that the 51.1 per cent of the internet banking users has account with public sectors bank and 48.2 per cent of the internet banking users has account with private sectors bank. From this table it shows us most of the internet banking user has account with public sector bank.

\section{Friedman Rank Correlation}

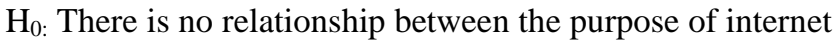
banking users with regards to their mean ranks.

Table - 2

\begin{tabular}{|l|c|c|c|}
\hline $\begin{array}{l}\text { Purpose of internet } \\
\text { banking usage }\end{array}$ & $\begin{array}{c}\text { Mean } \\
\text { Rank }\end{array}$ & $\begin{array}{c}\text { Chi-Squ } \\
\text { are }\end{array}$ & $\begin{array}{c}\text { P - } \\
\text { Value }\end{array}$ \\
\cline { 1 - 2 } Q10.1 Fund transfer & 4.74 & & \\
\cline { 1 - 2 } Q10.2 Ticket booking & 3.81 & \multirow{2}{*}{88.187} & $<0.001$ \\
\cline { 1 - 2 } Q10.3 Online shopping & 4.40 & & \\
\cline { 1 - 2 } Q10.4 Generate account & 4.24 & & \\
\hline statement & 3.90 & & \\
\hline
\end{tabular}

\section{Sources: Questionnaire Method} Inference
The Friedman rank correlation is applied to identify the most influenced factors among the two or more factors. According to the mean rank 4.74 the fund transfer is the most influenced factor in the purpose of internet banking users followed by online shopping with mean score of 4.40, generate account statement with mean rank of 4.24 , bill payment with mean score of 3.90 and the ticket booking 3.81 is the least usage among the customers. The p-value is less than $0.05(<0.001)$ therefore the framed null hypothesis is rejected at $5 \%$ level of significant. Hence there is some relation between the purposes of internet banking users with regards to their mean ranks.

\section{Age group Vs Usage Pattern of Internet Banking}

$\mathbf{H}_{\mathbf{0}}$ : There is no significant difference between the perceived usefulness, perceived ease of use and perceived risk in the factor of usage pattern of internet banking with regards to their different age groups

\begin{tabular}{|c|c|c|c|c|c|c|}
\hline \multicolumn{7}{|c|}{ Table - 4} \\
\hline & Age Group & $\mathbf{N}$ & Mean & S.D & $\begin{array}{c}\text { F- } \\
\text { Value }\end{array}$ & $\begin{array}{c}\text { P- } \\
\text { Valu } \\
\text { e }\end{array}$ \\
\hline \multirow{4}{*}{$\begin{array}{l}\text { Perceived } \\
\text { Usefulness }\end{array}$} & Young age & 31 & 20.35 & 3.168 & \multirow{4}{*}{.945} & \multirow{4}{*}{0.392} \\
\hline & Middle age & 60 & 21.18 & 2.561 & & \\
\hline & Old age & 30 & 20.63 & 3.157 & & \\
\hline & Total & 121 & 20.83 & 2.876 & & \\
\hline \multirow{4}{*}{$\begin{array}{l}\text { Perceived } \\
\text { Ease of Use }\end{array}$} & Young age & 31 & 17.90 & 3.400 & \multirow{4}{*}{.102} & \multirow{4}{*}{0.903} \\
\hline & Middle age & 60 & 18.10 & 3.323 & & \\
\hline & Old age & 30 & 17.77 & 3.655 & & \\
\hline & Total & 121 & 17.97 & 3.401 & & \\
\hline \multirow{4}{*}{$\begin{array}{l}\text { Perceived } \\
\text { Risk }\end{array}$} & Young age & 31 & 16.42 & 5.137 & \multirow{4}{*}{.347} & \multirow{4}{*}{0.707} \\
\hline & Middle age & 60 & 17.15 & 3.612 & & \\
\hline & Old age & 30 & 16.97 & 3.264 & & \\
\hline & Total & 121 & 16.92 & 3.959 & & \\
\hline
\end{tabular}

\section{Sources: Questionnaire Method}

\section{Inference}

The above table - 4 illustrates that the P-value of all factors $>0.392 / 0.903 / 0.707$ which is more than the prescribed value of 0.05 , hence the null hypothesis of all factors is accepted at $5 \%$ level of significance. Therefore there is no significant difference between the perceived usefulness, perceived ease of use and perceived risk in the factor of usage pattern of internet banking with regards to their different age groups. In the view of age group and internet banking usage pattern

when compared with other age group the middle age group customers are influenced more with mean rank of 21.18/18.10/17.15 respectively. 


\section{IMPLICATIONS}

Most of the customers maintain saving bank account with private sector banks they are using internet banking its will boost the money circulations of private sector banks. In the view of purpose of internet banking usage According to the mean rank 4.74 the fund transfer is the most influenced factor in the purpose of internet banking users followed by online shopping with mean score of 4.40, generate account statement with mean rank of 4.24 , bill payment with mean score of 3.90 and the ticket booking 3.81 is the least usage among the customers. Nearly everyone using internet banking for the intention of fund transfer therefore the appropriate banking industry could sustain the present service that will increase the internet banking user gradually. In the view of age group and internet banking usage pattern when compared with other age group the middle age group customers are influenced more. Hence the banking industry should provide more offers and awareness schemes for other age group customers that will lead the banking industry to a greater height.

\section{CONCLUSION AND RESEARCH FURTHERANCE}

This study will gives the better understanding about internet banking user's usage pattern and purpose. Further the concepts of internet banking explained by two methods namely use case and data flow diagram methods. Use case diagram method explained the processing of internet banking fund transfer and ticket booking on the other hand the data flow diagram enlightens the usage pattern like fund transfer, ticket booking, online shopping, generate account statement and bill payment this will demonstrate the internal and external processing of internet banking. The outcome of the research report will help the banking industry to take important decisions about internet banking usage. The suggestion should be more appropriate and relevant to the banking industry and customers. Further the same study could be extended as a comparative one. Moreover the internet banking usage tested with the customer perception and customer psychology.

\section{ACKNOWLEDGEMENT}

There are no research funds received from any organizations and research institutions. All the funds contributed by the authors of this article.

\section{REFERENCES}

1. Teo, M. T. (2000). Factors Influencing the Adoption of Internet Banking. Journal of the Association for Information Systems , 1-44.

2. Eta Wahab, O. S. (2013). Identifying Factors that Determine Intention to Use Electronic Banking: A Conceptual Study. Journal of Basic and Applied Scientific Research , 34-45 .

3. Kyritsi, I. S. (2014). Investigating the Determinants of Internet Banking Adoption in. Procedia Economics and Finance , $501-510$.

4. Makosana, M. S. (2014). Customers' Adoption of Electronic Banking. an Investigation on the Commercial Banking Industry in Zimbabwe. International Journal of Economics, Commerce and Management 1-13.

5. Sanjida Parveen, A. H. (2010). Adoption of e-banking in Bangladesh: An exploratory study. African Journal of Business Management 2718-2727.

6. Al-Fahim, N. H. (2013). An Exploratory Study of Factors Affecting the Internet Banking Adoption: A Qualitative Study among Postgraduate Students. Global Journal of Management and Business Research , $1-13$.
7. Eta Wahab, O. S. (2013). Identifying Factors That Determine Intention to Use Electronic Banking: A Conceptual Study. Middle-East Journal of Scientific Research , 1010-1022.

8. J, R. H. (2014). A Study on Factors Influencing Consumer Adoption of Internet Banking in India. International Journal of Business and General Management , 49-56.

9. Dzogbenuku, R. K. (2013). Banking Innovation in Ghana: Insight of Students' Adoption and. Journal of Internet Banking and Commerce $1-20$.

10. Adebayo AK, O. F. (2015). Factors Influencing Intention to Adopt Internet Banking by Postgraduate Students of the University of Ibadan, Nigeria. Journal of Internet Banking and Commerce , 1-10.

11. Mohamad Fauzan Noordin, A. S. (2011). Factors influencing the adoption of M-commerce: An exploratory Analysis. Proceedings of the 2011 International Conference on Industrial Engineering and Operations Management , 22 - 24

12. Ekramul Gani Md Ekram, A. M. (n.d.). Malaysian Users' awareness towards Adoption of internet Banking, among Malaysian Consumers. 201-215.

13. D.Davis, F. (1989). Perceived Usefulness, Perceived Ease of Use, and User Acceptance of Information Technology. MIS Quarterly , 319-340.

14. Davis, F. D. (1991). Useer Acceptance of Information Technology: System Characteristics, User perceptions and behavioural impact. Man-Machine Studies , 475-487.

15. Davis, F. D. (1989). User Acceptance of Computuer Technology : A Comparison of Two Theoretical Models . Management Science 982-1003.

16. Begum, N. J. (2008). The role of perceived usefulness, perceived ease of use, security and privacy, and customer attitude to engender customer adaptation in the context of electronic banking. African Journal of Business Management, 33-39.

17. Röcker, C. (2009). Perceived Usefulness and Perceived Ease-of-Use of Ambient Intelligence Applications in Office Environments. Springer Verlag, Heidelberg, Germany , 1052-1061.

18. Tandrayen-Ragoobur, V. A. (2011). Is Mauritius Ready to E-Bank? From A Customer and Banking Perspective. Journal of Interne Banking and Commerce , 1-17.

19. Nasri, W. (2011). Factors Influencing the Adoption of Internet Banking in Tunisia. International Journal of Business and Management , 143-160.

20. Nor, A. S.-A. (2013). Internet Banking Adoption: Integrating Technology Acceptance Model and Trust. European Journal of Business and Management , 207-215.

21. Rosmaini Bin HJ Tasmin, A. A. (2012). An Exploratory Study on Adoption of Electronic Banking: Underlying ConsumerBehaviour and Critical Success Factors. Case of Nigeria. Business and Management Review , $01-06$.

22. Gikonyo, K. J. (2014). Factors Influencing the Adoption of Internet Banking In Kenya. Journal of Business and Management , 60-65.

23. Murthy, S. S. (2013). Factors Influencing the Behavioural Intention to Adopt Internet Banking: an Empirical Study in India. Journal of Arts, Science \& Commerce , 77-91.

24. BK, A. (2015). The Impact of Customer Demographic Variables on the Adoption and Use of Internet Banking in Developing Economies. Journal of Internet Banking and Commerce , 1-11.

25. Dalhatu, B. U. (2014). Nigerian Retail Customers' Adoption of Online Banking in an Islamic Bank. Global Business and Managemen Research: An International Journal , 237-245.

26. Babbie, Earl (2011). The basics of social research. Chapman University in southern California: Wadsworth, Cengage Learning, p-96.

27. N.Ross, K. (2005). Sample design for educational survey research: Quantitative research methods in educational planning. Pairs: UNESCO Publications

\section{AUTHORS PROFILE}

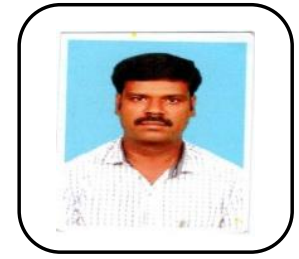

Dr. R. Ganesh, is an Assistant Professor in the Department of Commerce in Guru Nanak College, Velachery, Chennai- 42. He is a passionate academician with 10 years of experience, He has published over 6 articles in national and international referred journals in the area of marketing, finance and HR etc.

Published By: and $\mathrm{Hum}_{\mathrm{n}}$ 


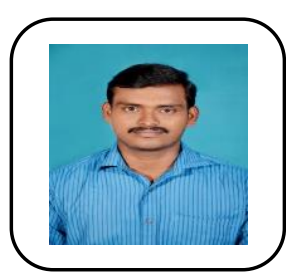

Dr. G. Prabu, is an Assistant Professor in the Department of Commerce in Guru Nanak College, Velachery, Chennai- 42. He is a passionate academician with 3 years of experience, He has published over 7 articles in national and international referred journals in the area of marketing, finance and HR etc., 